\title{
State of the Knowledge and Approach of School Teachers Regarding various Adolescent Health Issues from the Sangli District (Maharashtra), India: An Urban-Rural Difference
}

\author{
Waghachavare Vivek Baliram ${ }^{1}$, Chavan Vishwajeet Manohar ${ }^{1 *}$, Dhumale Girish Bhimrao ${ }^{2}$
}

\section{Waghachavare Vivek Baliram ${ }^{1}$, Chavan Vishwajeet Manohar ${ }^{1 *}$, Dhumale Girish Bhimrao²}

\section{${ }^{1}$ Assistant Professor, Department of Community Medicine, Bharati Vidyapeeth Deemed University Medical College \& Hospital, Sangli, Maharashtra, INDIA. \\ ${ }^{2}$ Professor \& Head, Department of Com- munity Medicine, Bharati Vidyapeeth Deemed University Medical College \& Hospital, Sangli, Maharashtra, INDIA. \\ Correspondence \\ Dr. Chavan Vishwajeet Manohar Assistant Professor, Department of Community Medicine, Bharati \\ Vidyapeeth Deemed University Medical College \& Hospital, Sangli, Maharashtra, INDIA. \\ Mobile no: +91-9503780277 \\ Email: vivek416416@gmail.com \\ History \\ - Submission Date: 27-01-2017 \\ - Revised Date: 27-04-2017 \\ - Accepted Date: 10-11-2017}

DOI : 10.5530/ijmedph.2017.4.38

Article Available online

http://www.ijmedph.org/v7//4

\section{Copyright}

(C) 2017 Phcog.Net. This is an openaccess article distributed under the terms of the Creative Commons Attribution 4.0 International license.

\begin{abstract}
Introduction: School teachers can play an important role be identifying problems of adolescents and guide them towards healthy adolescence. Hence the current research was planned to study, their involvement in adolescent health. Methods: A cross-sectional study was conducted among the teachers from secondary schools in Sangli district (Maharashtra, India). Informed consent was taken. Data was collected by self-administered questionnaire during August-2015 to March-2016. Two-stage sampling technique was used; for the first stage stratified random sampling and convenience sampling for the second. Descriptive statistics, Mann-Whitney test and binary logistic regression were used for statistical analysis. Results: Seven hundred and five participants were included in final analysis. Mean score of "involvement in adolescent health scale" was $48.4 \pm 13$. Teachers from the urban area had a higher score but the urban-rural difference was not statistically significant. By using binary logistic regression, adolescent health training was found to be the best predictor for involvement in adolescent health. Mean scores for attitude, awareness and practices subscales were $70.2( \pm 23), 48.7( \pm 17.1)$ and $26.1( \pm 15)$ respectively. Conclusion: Involvement of the teachers in adolescent health was low; teachers from urban area fared slightly better than rural counterparts. The attitude of the teachers regarding adolescent health was good, however, awareness and practices were poor. Adolescent health training helped in the better involvement of the teachers.

Key words: Adolescent Health, Adolescent Behavior, School Teachers, Awareness, India.
\end{abstract}

\section{INTRODUCTION}

The word adolescence is derived from Latin word, adolescere meaning "growing to maturity". Adolescence is an important phase comprising of psychological, physical and social change, which results in the development of new behaviours, thinking and outlook. These changes play an important part in adult life. ${ }^{2}$ Adolescents frequently suffer from problems like substance abuse, STIs, HIV/AIDS, psychological problems and reproductive health issues. ${ }^{3}$ These problems can have lifelong implications. ${ }^{4}$ However proper medical advice are rarely sought due to barriers like stigma attached to these problems, lack of availability, costs, lack of knowledge, anxiety about confidentiality, gender bias, social bias, etc. ${ }^{5,6}$ Hence we have to go beyond health specialists to meet their needs.

School-based interventions can lead to reduced substance misuse, violence, and other antisocial behaviours in adolescents. ${ }^{7}$ It is recommended to incorporate health issues in the curriculum. ${ }^{8}$ Thus, involvement of teachers can prove of great importance in maintaining adolescent health.

But according to some researchers the knowledge of school teachers regarding adolescent health is lacking. ${ }^{9}$ Similarly, the data regarding their active involvement in adolescent health is inadequate. Hence the current study was planned with the aim to assess involvement of school teachers in the adolescent health.

\section{MATERIALS AND METHODS}

It was a cross-sectional study conducted among school teachers from the secondary schools of Sangli district (Maharashtra) India; during August-2015 to March-2016. In a previous such Indian study, partial knowledge regarding adolescent health was observed in $55.2 \%$ teachers. ${ }^{9}$ Based on those findings calculated sample size (prevalence, $\mathrm{p}=55.2 \%$ i.e. 0.552, $q=1-p, \alpha=0.05$, allowable error, $d=5 \%$ and applying formula $\mathrm{Z}_{\alpha}^{2} \mathrm{pq} / \mathrm{d}^{2}$ ) was 380 . Assuming losses due to incomplete questionnaires at $15 \%$, the sample size was adjusted to $437 \cong 450$. The observed ratio urban: rural teachers was roughly $1: 4$, hence it was decided to include minimum 90 and 360 teachers from urban and rural area respectively. It was observed that, each school had at least ten teachers. So, we decided to randomly select 10 urban and 36 rural schools. Two stage sampling was used for the data collection. Stratified random sampling was used for the first stage. Sangli district was divided in two strata, urban \& rural. Schools in each stratum were listed and randomly selected. Second stage was convenience 
sampling i.e. all the teachers in the selected school were invited for participation. Seven hundred forty-eight teachers from the selected schools participated in the study. Voluntary informed consent was the selection criteria. The due ethical and administrative permissions were obtained for the study.

The study tool was self-administered, pre-tested questionnaire developed with the help of specialists from the field, experienced faculty and published literature. ${ }^{10,11,12,13}$ A pilot study was conducted; the questionnaire was modified and finalized after it. The data from the pilot study was not included in the final analysis. The questionnaire consisted of socio-demographic factors and a scale for assessing their involvement in the adolescent health. The scale had three subscales; each related to awareness, attitude and practices regarding adolescent health. The awareness subscale measured understanding of the teachers regarding mental health issues and behavioural problems in adolescents. The attitude subscale primarily enquired about their attitude towards adolescent reproductive health problems. The practices subscales probed into their actual enactment on encountering problems like mental health issues, behavioural problems and substance abuse among adolescent students. For each of subscales the desired answer was awarded one point. Total sum of points for each subscale was converted to percentage. The mean percent score of all the three subscales was calculated as a score for assessing, "Involvement of the teachers in adolescent health". After discussion with field experts and based on observations of pilot study, it was decided that score of $\geq 50 \%$ to be considered as good and $<50 \%$ as poor for the involvement scale and each subscale. All the three subscales had good internal consistency. The Cronbach's $\alpha$, for awareness, attitude and practices subscales was $0.57,0.71$ and 0.70 respectively. Strict confidentiality and privacy was maintained during data collection.

Percentages, descriptive statistics, Mann Whitney test and Binary logistic regression were used for statistical analysis. Analysis was done using Microsoft Excel 2003 and IBM SPSS Statistics-22 software.

\section{RESULTS}

There were seven hundred forty-eight study participants; the nonresponse rate was less than five percent. However, seven hundred five questionnaires were duly complete so included in the final analysis. On considering the permanent address, the participants belonging to urban and rural area were $185(26.2 \%)$ and $520(73.8 \%)$ respectively. Mean age and experience of the participants was $40.92( \pm 8.6)$ and $14.69( \pm 8.5)$ years respectively. Majority of the participants were males $419(59.4 \%)$ (Table 1). Seventy-five (10.6\%) participants were designated teachers, while $630(89.4 \%)$ were assistant teachers. Sixty-one (8.7\%) participants had undergone adolescent health training. The mean score of the involvement scale was 48.4 (Std. deviation \pm 12.9 , range 8.9-79.2); median and mode scores were 49.3 and 43.6 respectively. While the mean percent scores of subscales; awareness, attitude and practices regarding adolescent health were 48.7 (Std. deviation \pm 17.1 , range $0-95.5$ ), 70 (Std. deviation \pm 23 , range $0-100$ ) and 26.2 (Std. deviation \pm 15 , range $0-70.8 \mathrm{~S}$ ) respectively. The mode percent score for practices subscale was 0 , while for attitude and awareness was 71.4 and 57.3 respectively (Table 2).

Mean score for Involvement scales and its subscales was higher among urban participants as compared to rural except for attitude subscale; however, differences were not statistically significant (Figure 1). Gender was associated with awareness (Mann-Whitney $\mathrm{U}=28479.5, \mathrm{p}=0.03$ ) and attitude (Mann-Whitney $\mathrm{U}=28479.5, \mathrm{p}=0.03$ ) subscales. The mean awareness score was higher for females (51) than males (47.1). But males had scored better on attitude subscale with the mean score of 72.1 as compared to 67.6 in females.

There was no association of designation, experience and age with involvement scale, attitude subscale and practices subscale. The awareness

\begin{tabular}{cccc}
\multirow{2}{*}{ Table 1: Gender and permanent residence of study population } \\
Gender & \multicolumn{2}{c}{ Permanent Address } & Total \\
& Rural & Urban & \\
Female & 191 & 95 & 286 \\
& $66.8 \%$ & $33.2 \%$ & $100 \%$ \\
Male & 329 & 90 & 419 \\
& $78.5 \%$ & $21.5 \%$ & $100 \%$ \\
Total & 520 & 185 & 705 \\
& $73.8 \%$ & $26.2 \%$ & $100 \%$
\end{tabular}

\begin{tabular}{ccccc}
\multicolumn{4}{c}{ Table 2: Scores of participants for Involvement scales and it's subscales } \\
$\begin{array}{ccccc}\text { Awareness } \\
\text { regarding } \\
\text { adolescent } \\
\text { health }\end{array}$ & $\begin{array}{c}\text { Attitude } \\
\text { towards } \\
\text { adolescent } \\
\text { health }\end{array}$ & $\begin{array}{c}\text { Practices } \\
\text { regarding } \\
\text { adolescent } \\
\text { health }\end{array}$ & $\begin{array}{c}\text { Involvement } \\
\text { in } \\
\text { adolescent } \\
\text { health }\end{array}$ \\
Mean & 48.7 & 70.2 & 26.1 & 48.4 \\
Median & 51.2 & 71.4 & 26.0 & 49.3 \\
Mode & 57.3 & 71.4 & 0.0 & 43.6 \\
Std. Deviation & 17.1 & 23.0 & 15.0 & 12.9 \\
Minimum & 0.0 & 0.0 & 0.0 & 8.9 \\
Maximum & 95.5 & 100.0 & 70.8 & 79.2
\end{tabular}

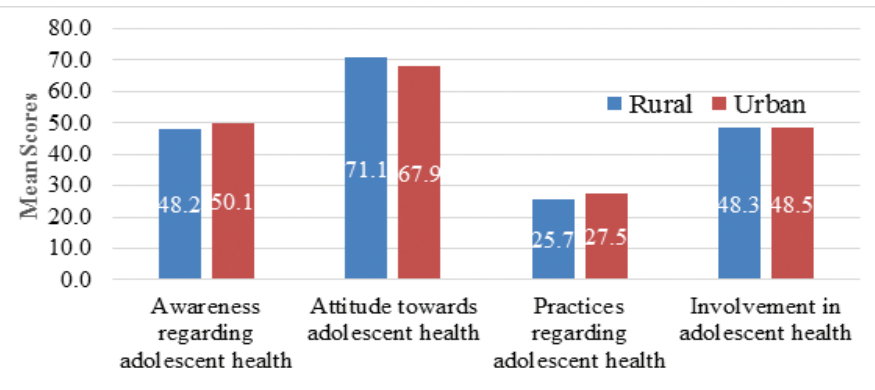

Figure 1: Comparing mean scores of Involvement scale and it's subscales for urban and rural teachers.

subscale was associated with age (Kruskal-Wallis test; chi-square $=13.3$, $\mathrm{p}=0.004$ ) and experience (Mann-Whitney $\mathrm{U}=28479.5, \mathrm{p}=0.03$ ). The mean awareness score was highest at 53.4 in the age group $\leq 30$ years; followed by $31-40$ years (49.8), 41-50 years (46.7) and $>50$ years (46.2). Similarly mean awareness score was higher for those having experience $\leq 5$ years (53.2) than $>5$ years (47.8). Participants undergone adolescent health training had higher mean for the involvement scale and all the subscales (Table 3).

On considering the interpretation of the scale; good score for involvement was observed in 329(46.7\%) participants. Binary logistic regression was applied using Backward Wald's method to find best predictors for involvement scales and its subscales. Age and permanent address (urban or rural) were significant predictors for awareness regarding adolescent health (Table $4 \mathrm{~A})$. Awareness was better in younger $(\mathrm{OR}=0.747)$ and urban $(\mathrm{OR}=1.426)$ teachers as compared to older and rural teachers respectively. Most significant predictor for attitude (Table $4 \mathrm{~B}$ ) and practices (Table $4 \mathrm{C}$ ) regarding adolescent health was adolescent health 


\begin{tabular}{|c|c|c|c|c|c|c|c|c|}
\hline \multirow[b]{2}{*}{ Scale Scores } & \multirow{2}{*}{$\begin{array}{c}\text { Adolescent } \\
\text { health training }\end{array}$} & \multirow{2}{*}{$\begin{array}{c}\text { Mean Score } \\
\quad( \pm \text { Std. } \\
\text { deviation) }\end{array}$} & \multicolumn{6}{|c|}{ Mann-Whitney Test } \\
\hline & & & $\begin{array}{l}\text { Mean } \\
\text { Rank }\end{array}$ & Sum of Ranks & $\begin{array}{c}\text { Mann- } \\
\text { Whitney U }\end{array}$ & Wilcoxon W & Z & P-Value \\
\hline \multirow{2}{*}{$\begin{array}{c}\text { Awareness } \\
\text { regarding } \\
\text { adolescent health }\end{array}$} & No & $48.6( \pm 17.1)$ & 352.1 & 226760.5 & \multirow[t]{2}{*}{19070.5} & \multirow[t]{2}{*}{226760.5} & \multirow[t]{2}{*}{-0.4} & \multirow[t]{2}{*}{0.707} \\
\hline & Yes & $49.5( \pm 17.9)$ & 362.4 & 22104.5 & & & & \\
\hline \multirow{2}{*}{$\begin{array}{l}\text { Attitude towards } \\
\text { adolescent health }\end{array}$} & No & $69.1( \pm 22.9)$ & 342.2 & 220405.5 & \multirow[t]{2}{*}{12715.5} & \multirow[t]{2}{*}{220405.5} & \multirow[t]{2}{*}{-4.6} & \multirow[t]{2}{*}{0.000} \\
\hline & Yes & $82.7( \pm 20.4)$ & 466.5 & 28459.5 & & & & \\
\hline \multirow{2}{*}{$\begin{array}{l}\text { Practices regarding } \\
\text { adolescent health }\end{array}$} & No & $25.8( \pm 14.8)$ & 347.9 & 224055.0 & \multirow[t]{2}{*}{16365.0} & \multirow[t]{2}{*}{224055.0} & \multirow[t]{2}{*}{-2.2} & \multirow[t]{2}{*}{0.031} \\
\hline & Yes & $29.4( \pm 16.2)$ & 406.7 & 24810.0 & & & & \\
\hline \multirow{2}{*}{$\begin{array}{l}\text { Involvement in } \\
\text { adolescent health }\end{array}$} & No & $47.8( \pm 12.8)$ & 344.7 & 222009.0 & \multirow{2}{*}{14319.0} & \multirow{2}{*}{222009.0} & \multirow{2}{*}{-3.5} & \multirow{2}{*}{0.000} \\
\hline & Yes & $53.9( \pm 12.9)$ & 440.3 & 26856.0 & & & & \\
\hline
\end{tabular}



$\mathrm{SE}=$ Standard error, $\mathrm{OR}=$ Odds ratio, $\mathrm{CI}=$ Confidence interval

\# - For categorical variables, reference category mentioned in the bracket.

training and residence respectively. Participants undergone adolescent health training $(\mathrm{OR}=2.903)$ and belonging to urban area $(\mathrm{OR}=3.744)$ had better attitude and practices regarding adolescent health respectively. The most significant predictor for Involvement in adolescent health was the adolescent health training $(\mathrm{OR}=2.340)$ (Table $4 \mathrm{D})$.

Six hundred thirty-six (90.2\%) and four hundred thirty (61\%) participants agreed to the need of imparting sex education and orientation towards contraception respectively. Six hundred forty-nine (92\%) participants supported the idea of separate health cell staffed with professionals in every school for students. Six hundred seventy-three (95.5\%) participants agreed that teachers are responsible for adolescent health. While $520(73.7 \%)$ were interested in receiving comprehensive adolescent health training. Six hundred fifty-five (92.9\%) and five hundred thirty- seven $(76.2 \%)$ participants identified non-teaching responsibilities and lack of parents' trust in them respectively, as major obstacles to their involvement in adolescent health.

\section{DISCUSSION}

Majority of teachers in our study had very good attitude towards adolescent health. Attitude of male teachers and teachers from rural area was better than females and teachers from urban area respectively. The overall awareness of the teachers regarding adolescent health issues was unsatisfactory. Younger teachers, female teachers and those belonging to urban area were better aware of adolescent health issues. In an Ethiopian study it was observed that teacher trainees from urban background and male trainees had better awareness regarding adolescent reproductive 
health. ${ }^{14}$ However that study was only regarding reproductive health as compared to multiple factors considered in our study. The practices were highly inadequate, proving that most of the teachers were unable to take required efforts regarding adolescent health issue. These were unsatisfactory among all age groups, both the genders and urban-rural area. Overall involvement of teachers had large scope for improvement. In a study conducted in the graduation colleges from Western Maharashtra (India), similar poor involvement of the teachers in the adolescent health was observed..$^{15}$ In a study conducted by Cohall et al. (New York, USA), it was observed that majority of the teachers were ready to take responsibility of disseminating health information and undergo staff development programme for the same. ${ }^{16}$ We had similar observation with majority of teachers accepted the responsibility in adolescent health and were ready to undergo requisite training. Those undergone training had better involvement. This indicates that although overall attitude is good, but lack of training resulted in poor knowledge and intervention. Most of the teachers agreed to the need of inclusion of sex education and orientation to contraception in the curriculum. They also agreed to the need of professional managed health cell for students in every school. Teachers believed that their involvement in non-teaching work and lack of parents' trust in them were important hurdles for any intervention.

\section{CONCLUSION}

Involvement of the teachers in adolescent health was low; teachers from urban area fared slightly better than rural counterparts. Teachers have good attitude and are ready to accept their responsibility in adolescent health. The teachers are interested in helping their students and are ready to take efforts for the same. However, they lack in proper knowledge and guidance regarding the issue. Their involvement can improve with proper training and encouragement.

Similarly, it is also advised to develop a health cell armed with professionals at every school.

The reduction of non-teaching or accessory work-load on the teachers by the school administration will help them in concentrating efforts towards adolescent health issues.

Teachers are in the position to help and mentor the adolescents. However, lack of parents' trust in them proves to be an important hindrance for the teachers. It is recommended to increase the parent-teacher interactions as well as to orientation of parents to adolescent health.

A dynamic and socio-culturally relevant, periodic evaluation system for assessing the involvement of teachers in adolescent health is strongly recommended.

\section{Limitations of the study}

The study is based on self-administered questionnaires, hence reporting bias cannot be eliminated. There may be over estimation of positive attitude and good practices. There is no mechanism to confirm the findings.

\section{CONFLICTS OF INTEREST}

None to declare.

\section{ACKNOWLEDGEMENT}

We would like to thank all the institutes and all the study participants for giving their valuable time and co-operation for this research.

\section{REFERENCES}

1. Webster's New World College Dictionary. 4th ed. New Delhi: Wiley - Dreamtech India Pvt Ltd; 2006. Adolescence.p.18.

2. Viner RM, Ozer EM, Denny S, Marmot M, Resnick M, Fatusi A, et al. Adolescence and the social determinants of health. Lancet 2012;379(9826):1641-52.

3. Nayar PD, Mehta R. Public Health Impact of Adolescent Health and Development. In: Bhave SY, editor. Bhave's Textbook of Adolescent Medicine. New Delhi: Jaypee Brothers Medical Publishers (P) Ltd; 2006. p.988-94.

4. Sawyer SM, Afifi RA, Bearinger LH, Blakemore SJ, Dick B, Ezeh AC, Patton GC. Adolescence: a foundation for future health. Lancet 2012;379(9826):1630-40.

5. Amdekar YK, Bhave SY. Development of Adolescent Specialty in India - Historical Perspective. In: Bhave SY, editor. Bhave's Textbook of Adolescent Medicine. New Delhi: Jaypee Brothers Medical Publishers (P) Ltd; 2006. p.4-7.

6. Tylee A, Haller DM, Graham T, Churchill R, Sanci LA. Youth-friendly primarycare services: how are we doing and what more needs to be done? Lancet 2007;369(9572):1565-73.

7. Sawyer SM, Afifi RA, Bearinger LH, Blakemore SJ, Dick B, Ezeh AC, Patton GC. Adolescence: a foundation for future health. Lancet 2012;379(9826):1630-40.

8. Cohall, AT, Cohall R, Dye B, Dini S, Vaughan RD and Coots S. Overheard in the Halls: What Adolescents Are Saying, and What Teachers Are Hearing, About Health Issues. J Sch Health [Internet]. 2007 [cited 2016 Aug 29];77(7):344-50. Available from: http://onlinelibrary.wiley.com/doi/10.1111/j.1746-1561.2007.00218.x/

9. Devgan S, Padda AS, Deepti SS, Kaur J, Ahlluwalia SK. Effectiveness of health education among female teachers of senior secondary regarding problems in adolescence. Indian Journal of community health 2012;24(2):107-12.

10. American Psychiatric Association. Diagnostic and statistical manual of mental disorders. $4^{\text {th }}$ edn. Text rev. Washington, DC: American Psychiatric Association, 2000.

11. Shastri PC, Shastri JP. Psychiatric disorders: Interview, assessment and diagnosis. In: Bhave SY, editor. Bhave's Textbook of Adolescent Medicine. New Delhi: Jaypee Brothers Medical Publishers (P) Ltd; 2006. p.749-52.

12. Greydanus DE, Yadav S. Substance abuse disorders. In: Bhave SY, editor Bhave's Textbook of Adolescent Medicine. New Delhi: Jaypee Brothers Medical Publishers (P) Ltd; 2006. p.800-5.

13. Jain T, Bisht. Impact of Violence. In: Bhave SY, editor. Bhave's Textbook of Adolescent Medicine. New Delhi: Jaypee Brothers Medical Publishers (P) Ltd; 2006. p.907-11

14. Shridevi kv. Awareness towards adolescent reproductive health among teacher trainees of Awassa, South Ethiopia. Review of Research [Internet]. 2012 [cited 2016 Aug 29];1:1-4. Available from: http://citeseerx.ist.psu.edu/viewdoc/downlo $\mathrm{ad}$ ?doi=10.1.1.300.6779\&rep=rep1\&type $=$ pdf

15. Waghachavare VB. Assessment of reproductive health, psychological and behavioural problems in late adolescents and role of teachers in dealing with it. [M.D. in Community Medicine]. Bharati Vidyapeeth Deemed University, Pune; 2014.

16. Cohall, A. T., Cohall, R., Dye, B., Dini, S., Vaughan, R. D. and Coots, S. Overheard in the Halls: What Adolescents Are Saying, and What Teachers Are Hearing, About Health Issues. Journal of School Health [Internet]. 2007 [cited 2016 Aug 29];77(7):344-50. Available from: http://onlinelibrary.wiley.com/doi/10.1111/ j.1746-1561.2007.00218.x/full

Cite this article : Baliram WV, Manohar CV, Bhimrao DG. State of the Knowledge and Approach of School Teachers Regarding various Adolescent Health Issues from the Sangli District (Maharashtra), India: An Urban-Rural Difference. Int J Med Public Health. 2017;7(4):183-6. 